\title{
PROFILE OF DRUGS USED IN PATIENTS WITH COVID-19 IN TWO HOSPITALS IN SANTA CATARINA
}

\author{
* Marco Aurélio Goulart, Juliana Cristina Lessmann Reckziegel, Márcio Costa Silveira de Ávila, \\ Victor Otávio Derossi, Rodrigo Canello, Rafael Sittoni Vaz, Tiago da Cruz Nogueira, Flávia Marin \\ Peluso and Letícia Oliveira Lunelli
}

Rua Silvio Zonta, 78, Rua sem saída ao lado da Nissan, Brazil

\begin{tabular}{|c|}
\hline ARTICLE INFO \\
\hline Article History: \\
\hline $\begin{array}{l}\text { Received } 09^{\text {th }} \text { March, } 2021 \\
\text { Received in revised form } \\
20^{\text {th }} \text { April, } 2021 \\
\text { Accepted } 11^{\text {th }} \text { May, } 2021 \\
\text { Published online } 30^{\text {th }} \text { June, } 2021\end{array}$ \\
\hline
\end{tabular}

\section{Key Words:}

COVID-19; Coronavirus;

Pandemic.

\begin{abstract}
Introduction: the first reports of the disease caused by SARS-Cov-2 emerged in Wuhan, China in late 2019 , and the causative agent and its ability to cause pneumonia, respiratory failure, and eventually death were soon identified more clearly. Based on the accurate study of the disease, several studies have emerged in an attempt to find a treatment, and there are currently more than 4,000 clinical studies related to the subject. Objectives: to perform a data research regarding the main drugs used in patients with COVID-19 in two hospitals in Santa Catarina, using these data to improve care. Method: a retrospective analysis of 683 medical records of patients admitted to infirmary and ICU beds in two hospitals in Santa Catarina. Results: in our study, high rates of antimicrobial use were observed, especially ceftriaxone and azithromycin, among the glucocorticoids dexamethasone was the most commonly used, anti-coagulant in varying doses was also common, other drugs such as hydroxychloroquine, ivermectin and hydrocortisone had lower rates of use. Discussion: currently the only drug with evidence of benefit in the outcome of mortality is dexamethasone when used in patients with moderate to severe symptoms, the other drugs should follow precise indications to have their use rationalized. Conclusion: to date, we still do not have a specific and effective therapy that results in clinical benefit in all cases of COVID-19, however, several drugs are still being tested, therefore, it is up to us to wait and act according to the current evidence.
\end{abstract}

Copyright ${ }^{C}$ 2021, Marco Aurélio Goulart. This is an open access article distributed under the Creative Commons Attribution License, which permits unrestricted use, distribution, and reproduction in any medium, provided the original work is properly cited.

Citation: Marco Aurélio Goulart, Juliana Cristina Lessmann Reckziegel, Márcio Costa Silveira de Avila, Victor Otávio Derossi, Rodrigo Canello, Rafael Sittoni Vaz, Tiago da Cruz Nogueira, Flávia Marin Peluso and Letícia Oliveira Lunelli. 2021. "Profile of drugs used in patients with covid-19 in two hospitals in santa catarina", International Journal of Development Research, 11, (06), 47999-48003.

\section{INTRODUCTION}

The first reports of the disease emerged in Wuhan in China in late 2019, an illness presenting with initial flu-like symptoms, tomographic findings compatible with pneumonia, and a potential risk of progression to severe acute respiratory syndrome, respiratory failure, and death. Soon the causative agent was identified as a coronavirus and named then SARS-CoV-2 and the disease caused by it became known as COVID-19 (WHO-c). Once the causative agent was identified, the incessant search for a specific treatment that could lead to reduced mortality, reduced symptoms, or even the prevention of the disease began. This challenge imposed by the pandemic scenario, led to the great challenge of the scientific community to create new drugs, however this process is time consuming and requires high investments, another strategy adopted by researchers, is the repositioning of drugs, i.e., to use drugs already known and approved by the regulatory agencies and test them on the new coronavirus (FERREIRA, L. G. 2020).
Using the keyword "COVID-19" as a search guide in the ClinicalTrials.gov database, the leading clinical trial registry in the United States and one of the leading in the world, one finds more than 4,600 registered clinical trials (as of the end of January 2021).

Objectives

- Conduct data collection regarding the profile of drugs used in COVID-19 patients.

- Compare the results found with references in the world medical literature.

- Use the results of this study to possibly improve the care of COVID-19 patients.

\section{METHODOLOGY}

This is a retrospective cross-sectional observational quantitative study. Developed in two hospital institutions in the state of Santa 
Catarina/Brazil, which offer public and free care linked to the Unified Health System. One institution, Hospital Tereza Ramos, has 144 active beds and the other, Hospital Florianópolis, has 50. Both are regional reference for the treatment of Covid-19. For data collection, medical records of all people admitted to the COVID Inpatient Units and COVID Intensive Care Units in 2020 were reviewed, totaling 683 records. It is pointed out that three medical records did not present information about medication, being excluded from the presentation of the results of this study. Inclusion criteria were: medical records of people affected or admitted to health units for COVID 19 care and aged over 18 years. For data collection, a questionnaire was developed containing socio-demographic and health information, which was recorded in an online application (SurveyMonkey®). The use of the application provided automated data entry in an Excel ${ }^{\circledR}$ spreadsheet, as well as the descriptive statistics. This study, linked to the research macro-project entitled "Health care in the hospital environment and the covid-19 pandemic: managerial, care, labor, patient safety, and care transition aspects", was approved by the ethics committee of the Federal University of Santa Catarina, under opinion no. 4,361,273, and complied with all the ethical aspects established in resolution 466/12 of the National Health Council. It was developed in the context of the Medical Residency in Health of the Hospital Tereza Ramos and the Professional Master of the Department of Nursing of the Federal University of Santa Catarina.

\section{RESULTS}

The analysis of 680 medical records of patients admitted to these hospitals, showed the following characteristics demonstrated in table 1.

Table 1. Characteristics

\begin{tabular}{ll}
\hline & TOTAL 680 \\
\hline Age (years) & 61.56 \\
Female & $292(42,94 \%)$ \\
Race & \\
White & $618(90.62 \%)$ \\
Indigenous & $1(0.15 \%)$ \\
Black & $24(3.52 \%)$ \\
Brown & $12(1.76 \%)$ \\
Other & $2(0.29 \%)$ \\
Not informed & $25(3.67 \%)$ \\
ICU Necessity & $200(29.54 \%)$ \\
COVID-19 diagnosis & $532(78.01 \%)$ \\
RT-PCR/Antigen & $481(70.42 \%)$ \\
Rapid test & $88(12.88 \%)$ \\
Sorological & $77(11.27 \%)$ \\
Not informed/performed & $37(5.41 \%)$ \\
Outcome & \\
High & $511(74.82 \%)$ \\
Death & $135(19.77 \%)$ \\
Transfer & $37(5.42 \%)$ \\
\hline
\end{tabular}

Table 2. Quantifies in a descending order the profile of the drugs used

Table 2. Medication

\begin{tabular}{ll}
\hline & $\mathrm{N}(\%)$ \\
\hline Enoxaparin & $624(92.44 \%)$ \\
Ceftriaxone & $623(91.30 \%)$ \\
Azithromycin & $581(86.07 \%)$ \\
Dexamethasone & $480(71.11 \%$ \\
Dipyrone/paracetamol & $422(62.52 \%)$ \\
Oseltamivir & $239(35.41 \%)$ \\
Hydrocortisone & $101(14.96 \%)$ \\
Hydroxychloroquine/Chloroquine & $29(4.3 \%)$ \\
Ivermectin & $20(2.96 \%)$ \\
\hline
\end{tabular}

\section{DISCUSSION}

A research for the treatment of COVID-19 was a constant subject in the scientific and medical environment, but also among lay people, taking over the media, dividing opinions even among big names in the scientific environment. Among the drugs tested, the antimalarial hydroxychloroquine was constantly among the most popular, among the antivirals the rendesevir appeared as the most promising, however other drugs like lopinavir/ritonavir with or without the combination with interferon-bla were also tested, among other antivirals, among the anti-parasitic the ivermectin, nitazoxanide, therapy also tested included the use of convalescent plasma to attempt direct treatment against the causative agent. Other non-specific measures are also tested, such as the use of glucocorticoids, use of Extracorporeal Circulation Oxygenation (ECMO), as measures routinely discussed in cases of patients with severe pulmonary pathologies, in addition to the use of anticoagulation.

Hydroxychloroquine: They represent the class of antimalarial drugs, therefore, they are drugs used in the treatment of malaria, however, they also have evidence of use for lupus erythematosus and rheumatoid arthritis. Mechanism of action is mainly through its effect as immunomodulator mainly on the innate immune system and its lysosomotropic actions (VENUTURUPALLI, S. 2012). The study of hydroxychloroquine in the treatment of COVID-19 emerged precisely betting on its immunomodulatory effect to contain the so-called storm of cytokines present in the pathophysiology of the disease, (YAO, X. et al 2020), besides presenting a potential antiviral effect (WHITE, N.J. et al 2020), having been tested in vitro, with positive results in the inhibition of SARS-CoV-2(YAO, X. et al 2020). Hydroxychloroquine came to be used in $4.3 \%$ of patients, based on early observational studies that suggested the drug's benefit against COVID-19. Subsequently, large clinical trials were conducted, the RECOVERY group, tested hydroxychloroquine in 1561 hospitalized patients versus 3155 to receive usual care with the ultimate goal of assessing the 28-day mortality endpoint. With results the study showed mortality $27.0 \%$ in the hydroxychloroquine group versus $25.0 \%$ in the usual care group (Odds ratios $1.09 ; 95 \%$ CI, 0.97 to $1.23 ; \mathrm{P}=0.15$ ) (RECOVERY-b). Another study, now using hydroxychloroquine with or without azithromycin in patients with mild to moderate cases of COVID-19, also showed no benefit from the drug, considering the clinical status after 15 days as the final endpoint.(CAVALCANTI, A.B. et al 2020). Based on the scientific evidence currently available, there is no evidence of clinical benefit in the use of hydroxychloroquine/ chloroquine in patients with mild, moderate or severe conditions. The use of this drug is not recommended for the treatment of COVID-19 in any phase, according to the main guidelines worldwide (National Institutes of Health) (WHO-d).

Dexamethasone: Dexamethasone, a synthetic glucocorticoid agent with anti-inflammatory action and antiemetic effects, has been used over the years in the treatment of various clinical conditions as an alternative drug in the treatment of acute or chronic adrenal insufficiency and adrenal crisis (BORNSTEIN, S.R, et al. 2016), in the prevention and treatment of emesis related to chemotherapy or radiotherapy regimens (HESKETH P.J., et al. 2020), in the treatment of asthma (GINA), in the treatment of brain edema caused by tumors (RYKEN, T.C. et al, 2010). The use of glucocorticoids in patients with acute respiratory distress syndrome (ARDS) has been studied for many years, and has also been studied in other past pandemics. In the setting of COVID-19, dexamethasone was studied by the RECOVERY group in the UK, comparing the effects of low-dose (6 $\mathrm{mg}$ orally or parenterally) dexamethasone for ten days in 2,104 patients with COVID-19 versus 4,321 patients on the usual treatment adopted so far(RECOVERY-a). The overall mortality in patients using dexamethasone was lower than in the control group $(22.9 \%$ vs. $25.7 \%$ ). However, benefit was shown at the expense of drug use in patients receiving some type of ventilator support, in those on invasive mechanical ventilation where the greatest benefit was seen ( $29.3 \%$ vs. $41.4 \%$; Odds ratio, $0.64 ; 95 \%$ CI, 0.51 to 0.81 ), but also in those requiring oxygen supplementation but not on invasive mechanical ventilation ( $23.3 \%$ vs. $26.2 \%$; Odds ratio, $0.82 ; 95 \% \mathrm{CI}$, 0.72 to 0.94 ), however, this same benefit was not demonstrated among the group of patients who did not require oxygen support $(17.8 \%$ vs. $14.0 \%$; Odds ratio $1.19 ; 95 \%$ CI, 0.91 to 1.55$)$. The 
benefit of a glucocorticoid in COVID-19 has a sound pathophysiological basis, as it is known to cause an exacerbated systemic inflammatory process, with elevation of several cytokines and inflammatory markers including type I interferon, interleukin-7, $1 \beta$, -6, and TNF-a (YUKI, K. 2020), IL-10, granulocyte colonystimulating factor (G-CSF), monocyte chemoattractant protein 1 (MCP1), macrophage inflammatory protein (MIP) $1 \alpha$, and tumor necrosis factor (TNF)- $\alpha$ (YOSHIKAWA, T. et al 2019). Virusinfected lung epithelial cells produced IL-8 and IL-6, consequently, the more severe, the higher the levels of these interleukins(YUKI, K. 2020). In our study, dexamethasone was used in $71.11 \%$ of the patients, which is relatively high; however, it is important to understand why almost $1 / 3$ of the patients did not receive the drug, the only one with a level of evidence of mortality reduction. In our understanding, the high rates of non-use of dexamethasone is justified by the non-application in patients with low percentages of pulmonary involvement seen on tomography images, who were often hospitalized for reasons other than dyspnea and hypoxemia, following the current recommendations. Based on current evidence, including a meta-analysis conducted by the WHO itself, the use of dexamethasone is recommended for the treatment of COVID-19 in critically ill patients, being understood as severe, those who need oxygen therapy support (WHO-a) (WHO-b), and its use is not recommended in cases of patients with non-severe conditions (WHOa) (National Institutes of Health) (WHO-d).

Hydrocortisone: The use of hydrocortisone in our series is not related to the treatment of COVID-19 but to conditions that require higher doses of glucocorticoids, especially patients with evidence of bronchospasm due to pulmonary diseases such as COPD or asthma.

Ivermectin: Ivermectin is considered to be an anti-parasitic drug, with clear evidence of use against certain conditions such as onchocerciasis and strongyloidiasis, however it is also an option for treatments of various intestinal hematoids including ascariasis, trichuriasis and enterobiasis, the cutaneous larva migrans and other ectoparasitic infections including scabies and lice. In addition to its already defined anti-parasitic effects, ivermectin is studied in various contexts in an attempt to define its potential benefit for treating a range of diseases, with its antimicrobial, antiviral and anticancer properties (CRUMP, A. et al 2011). Ivermectin was then tested in vitro against SARS-CoV-2, showing the ability to reduce viral RNA 5000 -fold in 48h (CALY, L. et al 2020). Subsequently a retrospective study of 280 patients, 173 treated with ivermectin and 107 without ivermectin, were reviewed. Mortality in the ivermectin group was lower compared to the group without the drug $(15.0 \%$ vs $25.2 \%$; OR, $0.52 ; 95 \%$ CI, 0.29-0.96; P $=0.03$ ) (RAJTER, J.C. et al 2021). The use of the drug occurred in $2.96 \%$ of our patients, its use was initially based on initial evidence that suggested its benefit in patients with COVID-19 (CALY, L. et al 2020), later the use of ivermectin was restricted to its indication in anti-parasitic dose for patients with prolonged hospitalization and using dexamethasone with risk of immunosuppression and evolution with strongyloides hyperinfection and its disseminated form (LUVIRA, V. et al 2016). Studies have pointed to increased viral clearance rate in patients who have used ivermectin (AHMED, S. et al 2020). However, to date no clinical trial has been able to prove or disprove the benefits of ivermectin in this group of patients, so its use is not indicated, however, it remains a potential study drug for treatment (National Institutes of Health) (WHO-d).

Convalescent plasma: Convalescent plasma obtained from individuals who have recovered from COVID-19 has the potential effect of creating passive immunity in patients, its use has been tested in other infections, with uncertain benefit. In a clinical trial with 103 patients, treatment with convalescent plasma was associated with a negative viral PCR conversion rate at 72 hours in $87.2 \%$ of the convalescent plasma group vs $37.5 \%$ of the control group (Odds Ratio 11.39 [95\% CI, 3.91-33.18]; P <0.001), however this effect did not demonstrate clinical benefit, the endpoint of clinical improvement after 28 days, was $51.9 \%$ of the convalescent plasma group vs $43.1 \%$ in the control group (Odds ratio 1.40 [95\% CI, 0.79-2.49]; P = 0.26 ), in those with severe disease $91.3 \%$ of the convalescent plasma group vs $68.2 \%$ of the control group (Odds ratio 2.15 [95\% CI, 1.07 4.32]; $\mathrm{P}=0.03)$. There was no significant difference in 28-day mortality ( $15.7 \%$ vs $24.0 \%$; Odds Ratio, 0.59 [95\% CI, 0.22-1.59]; P $=0.30)$ or time from randomization to discharge $(51.0 \%$ vs $36.0 \%$ with discharge on day 28; HR, 1.61 [95\% CI, 0.88-2.95]; $\mathrm{P}=$ 0.12)(LI, L. et al 2020). Based on the currently available evidence, there is still no satisfactory clinical evidence to recommend or not the use of convalescent plasma in pacemakers with COVID-19, with any degree of severity or time of evolution (National Institutes of Health) however the WHO does not recommend its use outside the context of clinical trials(WHO-d).

Anticoagulation: The discussion about the use of anticoagulants in patients with COVID-19 arose after the first reports of thrombotic complications linked to the disease; post-mortem studies of 21 individuals with COVID-19, in which histological analysis was performed on 11 of them, evidence of pulmonary thromboembolism was found in 4 , capillary microthrombi in 5 . Three had evidence of thrombotic microangiopathy in the glomerular capillaries and all 11 were receiving some form of anticoagulation(MENTER, T. et al 2020). In retrospective analyses of 637 ICU patients who required mechanical ventilation documented VTE in 45 ( 7.2 percent) despite prophylactic anticoagulation (Hill, J.B. et al 2020), this high prevalence of VTE is associated with higher mortality rates in patients with COVID-19 (Odds ratio, 1.37; 95\% CI 1.02-1.86) (BILALOGLU, S. et al 2020). The prevalence of DVT in ICU patients is found to be 65 to $69 \%$ routinely sought and appears to occur despite the use of prophylactic anticoagulation (NAHUM, J. et al 2020). In those patients discharged from the hospital, VTE was present in $0.14 \%$ of patients after a mean follow-up of 14.6 days (Hill, J.B. et al 2020). However, according to the National Institutes of Health, there are insufficient data to support the indication for VTE screening in asymptomatic patients for such, in any scenarios of severity or time of illness. Occurrence of arterial thrombosis is also described and a prevalence of $8.4 \%$ has been reported in ICU patients, with stroke and acute myocardial infarction being the most common (BILALOGLU, S. et al 2020). According to the National Institutes of Health, in its guideline on the use of anticoagulants and platelet anti-aggregants in patients with COVID-19, the use of anticoagulants in prophylaxis doses is recommended for hospitalized patients, respecting the usual doses indicated for non-COVID-19 cases, with no indication for the use of higher doses (National Institutes of Health). The use of prophylactic anticoagulation can be considered in patients who have been discharged from the hospital and have a low risk of bleeding and a high risk of VTE. Currently rivaroxaban $10 \mathrm{mg}$ per day is indicated as a prophylactic drug for these cases. Anticoagulation at therapeutic doses should be instituted in every patient with a diagnosis of VTE or high suspicion of VTE, taking into account the risk of bleeding (National Institutes of Health). In our study, $92.44 \%$ of the patients received some type of anticoagulation, whether prophylactic, therapeutic, or adjusted according to expert opinion. The use of anticoagulants was routinely performed for most patients, not only in cases of high risk of bleeding and low risk of VTE, in addition, those patients who presented low risk of bleeding and high risk of VTE were discharged with the orientation to maintain the use of rivaroxaban in prophylactic dose.

Oseltamivir: The use of oseltamivir in a patient with COVID-19 is not related to any direct benefit on the virus but rather for the treatment of a possible influenza virus infection that may be associated. Therapy should be started empirically at an early stage and discontinued when the diagnosis is ruled out through nondetection of nucleic acid in respiratory tract specimens (National Institutes of Health). In our study, oseltamivir was used in $35.41 \%$ of patients, which is a drug that is part of the initial treatment protocols for patients admitted to these hospitals, however, contrary to the current indication of the National Institutes of Health, its use was routinely suspended as soon as the diagnosis of COVID-19 was established by viral RNA detection by PCR, antigen detection or compatible serology, even if the diagnosis of co-infection by 
influenza virus was not ruled out, this fact did not occur due to the low availability of these tests.

Antibiotics: The routine use of azithromycin in non-hospitalized patients, in mild to moderate cases, has not proven to benefit the clinical status after 15 days of treatment (CAVALCANTI, A.B. et al 2020), its use in hospitalized patients has also not shown benefit in clinical improvement, reduced need for invasive mechanical ventilation or death outcome (RECOVERY). In hospitalized patients, the routine use of antibiotics is not recommended, and should be instituted when there is suspicion of associated bacterial infection, or in cases of doubt. Empirical treatment can be initiated, after which the antimicrobial spectrum must be adjusted to the results of culture and anti-biogram tests (National Institutes of Health) (WHO-d). Despite the indications proposed by the National Institutes of Health, our patients received antibiotics in a protocol manner upon admission, with ceftriaxone and azithromycin being the most used antibiotics (92.30 and $86.07 \%$ respectively), they could be stopped early as the suspicion of bacterial co-infection proved unlikely or null, the antimicrobial spectrum could be broadened as evidence of new infections.

\section{CONCLUSION}

With globalization, the way to do scientific research has become faster, and it is possible to conduct a large multicenter clinical trial in several countries around the world using, for example, just the application of an online questionnaire, or accessing databases remotely. This process has become even faster when it comes to a pandemic situation, where the discovery of a new drug, or new applicability of an old drug, may be responsible for saving the lives of thousands of people, in addition to the financial benefits generated for the pharmaceutical industry. As a result of the pandemic scenario, we have noticed a growing increase in the general population's interest in health issues, and we have started to witness in our daily life, lay people dealing with medical issues in a way to speak as real experts on the subject, questioning diagnoses and conducts of health professionals. Many times these people are based on popular sayings, people with social influence, politicians, or even other health professionals. In the current pandemic scenario, we are witnessing a true inversion of the doctor-patient relationship, where the doctor has become a mere prescriber of a medication or therapy required by the patient, some of them with no proven benefit and others already with results that show no benefit. In the intra-hospital scenario, high demands in wards and ICUs lead to the creation of care protocols, with the purpose of standardizing care, optimizing time, however, these protocols break what is most sacred in the doctor-patient relationship, humanization, treating each individual in a unique way, evaluating each case individually. The creation of protocols in our hospitals has led to the excessive use of antibiotics without proof of their real need. In the near future we will have to deal with the consequences of these decisions.

\section{REFERENCES}

AHMED, S. KARIM, M.M. ROSS, A.G. et al. A five-day course of ivermectin for the treatment of COVID-19 may reduce the duration of illness. Int J Infect Dis. 2020 Dec vol 103 pag 21416. doi: 10.1016/j.ijid.2020.11.191. Disponível em: https://www.ncbi.nlm.nih.gov/pmc/articles/PMC7709596/ Acessado em: 30/01/2021

BILALOGLU, S. APHINYANAPHONGS, Y. JONES, S. et al. Thrombosis in Hospitalized Patients With COVID-19 in a New York City Health System. JAMA. 2020 vol 324 n 8 pag 799801. doi:10.1001/jama.2020.13372 Disponível em: https://www. ncbi.nlm.nih.gov/pmc/articles/PMC7372509/ Acessado em $30 / 01 / 2021$.

BORNSTEIN, S.R, et al. Diagnosis and Treatment of Primary Adrenal Insufficiency: An Endocrine Society Clinical Practice Guideline. J Clin Endocrinol Metab. 2016 Fev Vol 101 nº $^{\circ}$. Pag
364-89. doi: 10.1210/jc.2015-1710 Disponível em: https://www.ncbi.nlm.nih.gov/pmc/articles/PMC4880116/ Acessado em 30/01/2021

CALY L, DRUCE, J.D. CATTON, M.G. et al. The FDA-approved drug ivermectin inhibits the replication of SARS-CoV-2 in vitro. Antiviral Res. 2020 vol $178 \mathrm{n}^{\circ}$ 104787. doi:10.1016/ j.antiviral.2020.104787. Disponível em: https://www.ncbi.nlm. nih.gov/pmc/articles/PMC7129059/ Acessado em: 30/01/2021

CAVALCANTI, A.B. ZAMPIERI, F.G. ROSA, R.G. et al. Hydroxychloroquine with or without Azithromycin in Mild-toModerate Covid-19. N Engl J Med. 2020 Nov vol 383 n 21 pag 2041-52. doi:10.1056/NEJMoa2019014. Disponível em: https://www.nejm.org/doi/10.1056/NEJMoa2019014?url_ver=Z $39.88-2003 \&$ rfr_id=ori:rid:crossref.org\&rfr_dat $=$ cr_pub $\% 20 \% 200$ pubmed Acessado em: 30/01/2021

CRUMP, A. ŌMURA, S. Ivermectin, 'wonder drug' from Japan: the human use perspective. Proc Jpn Acad Ser B Phys Biol Sci. 2011 vol 87 n $^{\circ} 2$ pag 13-28. doi:10.2183/pjab.87.13 Disponível em: https://www.ncbi.nlm.nih.gov/pmc/articles/PMC3043740/ Acessado em: 30/01/2021

FERREIRA, L. G. ANDRICOPULO, A. D. Medicamentos e tratamentos para a Covid-19. Estud. av., São Paulo , v. 34, n. 100, p. 7-27, Dec. 2020. https://doi.org/10.1590/s01034014.2020.34100.002. Disponível em: http://www.scielo.br/ scielo.php?script $=$ sci_arttext\&pid $=$ S0103-40142020000300007 $\& \operatorname{lng}=$ en $\& n r m=$ iso $>$. Acessado em: $30 / 01 / 2021$

GINA - Global Initiative for Asthma. Global strategy for asthma management and prevention 2020. Disponível em: https://ginasthma.org/wp-content/uploads/2020/04/GINA-2020full-report_final-_wms.pdf. Acessado em 30/01/2021 Acessado em $30 / 01 / \overline{2} 021$

HESKETH P.J., et al. Antiemetics: ASCO guideline update. J Clin $\begin{array}{llllll}\text { Oncol. } 2020 & \text { Vol } 38 . & N^{\circ} & 24 & \text { Pag } & \text { 2782-97. }\end{array}$ doi:10.1200/JCO.20.01296. Disponível em: https://ascopubs.org/ doi/10.1200/JCO.20.01296?url_ver=Z39.88-2003\&rfr_id $=$ ori:rid:crossref.org\&rfr_dat $=\overline{c r}$ pub $\% 20 \% 200$ pubmed Acessado 30/01/2021

HILL, J.B, GARCIA, D, CROWTHER, M, et al. Frequency of venous thromboembolism in 6513 patients with COVID-19: a retrospective study. Blood Adv. 2020;4(21):5373-5377. doi:10.1182/bloodadvances.2020003083

LI, L. ZHANG, W. HU, Y. et al. Effect of Convalescent Plasma Therapy on Time to Clinical Improvement in Patients With Severe and Life-threatening COVID-19: A Randomized Clinical Trial. JAMA. 2020 Ago vol $324 \mathrm{n}^{\circ} 5$ pag 460-470. doi:10.1001/jama.2020.10044. Disponível em: https://www.ncbi.nlm.nih.gov/pmc/articles/PMC7270883/ Acessado em: 30/01/2021

LUVIRA, V. TRAKULHUN, K. MUNGTHIN, $M$. et al. Comparative Diagnosis of Strongyloidiasis in Immunocompromised Patients. Am J Trop Med Hyg. 2016 Ago vol $95 n^{\circ} 2$ pag 401-4. doi: 10.4269/ajtmh.16-0068 Disponível: https://www.thelancet.com/journals/lancet/article/PIIS01406736(21)00149-5/fulltext Acessado em: 07/02/2021

MENTER, T. HASLBAUER, J.D. NIENHOLD, R. et al. Postmortem examination of COVID-19 patients reveals diffuse alveolar damage with severe capillary congestion and variegated findings in lungs and other organs suggesting vascular dysfunction. Histopathology. 2020 vol $77 \mathrm{n}^{\mathrm{o}} 2$ pag 198-209. doi:10.1111/his.14134 Disponível em: https://www.ncbi.nlm.nih.gov/pmc/articles/PMC7496150/ Acessado em: 30/01/2021

NAHUM, J. MORICHAU-BEAUCHANT, T. DAVIAUD, F. et al. Venous Thrombosis Among Critically Ill Patients With Coronavirus Disease 2019 (COVID-19). JAMA Netw Open. 2020 maio vol $3 \mathrm{n}^{\circ} 5$ doi:10.1001/jamanetworkopen.2020.10478 Disponível https://www.ncbi.nlm.nih.gov/pmc/articles/PMC7260620/ Acessado em: 30/01/2021

NATIONAL INSTITUE OF HEALTH. Coronavirus Disease 2019 (COVID-19) Treatment Guidelines. Disponível em: 
https://covid19treatmentguidelines.nih.gov/Acessado

em: $30 / 01 / 2021$

NATIONAL INSTITUTE OF HEALTH. ClinicalTrials.gov databases. U. S. National Library of Medicine. Disponível em: https://clinicaltrials.gov/ct2/home. Acessado em: 08/02/2021

RAJTER, J.C. SHERMAN, M.S. FATTEH, N. et al. Use of Ivermectin Is Associated With Lower Mortality in Hospitalized Patients With Coronavirus Disease 2019: The Ivermectin in COVID Nineteen Study. Chest. 2021 vol. 159 n 1 pag 85-92. doi:10.1016/j.chest.2020.10.009. Disponível em:https://www. ncbi.nlm.nih.gov/pmc/articles/PMC7550891/ Acessado em: $30 / 01 / 2021$

RECOVERY-a Collaborative Group, Horby P. et al. Dexamethasone in Hospitalized Patients with Covid-19 - Preliminary Report. N Engl J Med. 2020 Jul 17. doi:10.1056/NEJMoa2021436. Publicação online. Disponível em: https://www.nejm.org/doi/full/10.1056/NEJMoa2021436/ Acessando em: 30/01/2021

RECOVERY-b Collaborative Group, Horby P. et al. Effect of Hydroxychloroquine in Hospitalized Patients with Covid-19. N Engl J Med. 2020 vol. $383 \mathrm{n}^{\circ} 21$ Pag 2030-40. doi:10.1056/NEJMoa2022926. Disponível em: https://www.nejm.org/doi/full/10.1056/NEJMoa2022926 Acessado em 30/01/2021

RECOVERY-c Collaborative Group, Horby P. et al. Azithromycin in Hospitalised Patients with COVID-19: a randomised, controlled, open-label, platform trial. Lancet. 2021. Fev. Versão online doi: 10.1016/S0140-6736(21)00149-5. Disponível em: https://www.thelancet.com/journals/lancet/article/PIIS01406736(21)00149-5/fulltext Acessando em: 07/02/2021

RYKEN, T.C. et al. The role of steroids in the management of brain metastases: a systematic review and evidence-based clinical practice guideline. J Neurooncol. 2010 vol 96 n 1 pag 103-14. doi:10.1007/s11060-009-0057-4 Disponível https://www.ncbi.nlm.nih.gov/pmc/articles/PMC2808527/ Acessado em: 30/01/2021

VENUTURUPALLI, S. GUDSOORKAR, V. WALLACE, D. Reconsidering antimalarials in systemic lupus erythematosus: developments of translational clinical interest. J Rheumatol. 2012 Set Vol 39 n $^{\circ} 9$ pag 1769-71. doi: 10.3899/jrheum.111616. Disponível em: https://www.jrheum.org/content/39/9/1769.long Acessado em: 30/01/2021
WHITE, N.J. WATSON, J.A. HOGLUND, R.M. COVID-19 prevention and treatment: A critical analysis of chloroquine and hydroxychloroquine clinical pharmacology. PLoS Med. 2020 Sep vol $17 \mathrm{n}^{\circ}$ 9. doi:10.1371/journal.pmed.1003252. Disponível em: https://www.ncbi.nlm.nih.gov/pmc/articles/PMC7470382/ Acessado em: 30/01/2021

WHO-a. Corticosteroids for COVID-19. Living Guidance. 2020. Set. Disponivel em: https://www.who.int/publications/i/item/WHO2019-nCoV-Corticosteroids-2020.1 Acessado em: 30/01/2021

WHO-b Rapid Evidence Appraisal for COVID-19 Therapies (REACT) Working Group, STERNE, J.A.C. Association Between Administration of Systemic Corticosteroids and Mortality Among Critically Ill Patients With COVID-19: A Meta-analysis. JAMA. 2020 Out. vol 324 n $^{\circ} 13$ pag 1330-41. doi: 10.1001/jama.2020.17023. Disponível em: https://jamanetwork.com/journals/jama/fullarticle/2770279 Acessado em 30/01/2021

WHO-c. Director-General's remarks at the media briefing on 2019nCoV. Fev 2020. Disponível em: http:/www.who.int/dg/speeches/detail/who-director-general-sremarks-at-the-media-briefing-on-2019-ncov-on-11-february2020 Acessado em: 30/01/2021

WHO-d. Clinical management of COVID-19: Integrim guidance. 2020 Mai. Disponível em: https://www.who.int/publications/i/item/clinical-managementof-covid-19. Acessado em:

YAO, X. YE, F. ZHANG, M. et al. In Vitro Antiviral Activity and Projection of Optimized Dosing Design of Hydroxychloroquine for the Treatment of Severe Acute Respiratory Syndrome Coronavirus 2 (SARS-CoV-2). Clin Infect Dis. 2020 Jul vol 71 $\mathrm{n}^{\circ} 15$ pag 732- 39. doi: 10.1093/cid/ciaa237. Disponível em: https://www.ncbi.nlm.nih.gov/pmc/articles/PMC7108130/ Acessado em: 30/01/2021

YOSHIKAWA, T. et al. Severe Acute Respiratory Syndrome (SARS) Coronavirus-Induced Lung Epithelial Cytokines Exacerbate SARS Pathogenesis by Modulating Intrinsic Functions of Monocyte-Derived Macrophages and Dendritic Cells. J Virol. 2009 Abr. vol 83 n 7 pag 3039-48. DOI: 10.1128/JVI.01792-08. Disponível em: https://www.ncbi.nlm.nih.gov/pmc/articles/PMC2655569/ Acessado em: 30/01/2021

YUKI, K. FUJIOGI, M. KOUTSOGIANNAKI, S. COVID-19 pathophysiology: A review. Clin Immunol. 2020 vol $215 \mathrm{n}^{\circ}$ 108427. Publicação online. doi: 10.1016 / j.clim.2020.108427. Disponível em: https://www.ncbi.nlm.nih.gov/pmc/ articles/ PMC7169933/. Acessado em 30/01/2021 